\title{
Municipal strategies for introducing housing on industrial estates as part of compact-city policies in the Netherlands
}

\section{Willem Korthals Altes, Milly Tambach}

TU Delft, OTB Research Institute for Housing Urban and Mobility Studies, Jaffalaan 9, 2628 BX Delft, The Netherlands

w.k.korthalsaltes@tudelft.nl

Published as: Korthals Altes, WK \& Tambach, M (2008). Municipal strategies for introducing housing on industrial estates as part of compact-city policies in the Netherlands. Cities, 25(4), 218-229. doi:10.1016/j.cities.2008.04.005

\begin{abstract}
Promoting mixed-use development is part of policies aimed at enhancing urban quality. Until recently, however, industry and housing have rarely been found together in the same development as there is a long tradition of keeping these functions separate. As part of a compact-city policy, Dutch local authorities are in the process of introducing housing on single-function industrial estates developed after World War II. Local governments are looking for strategies and instruments that will help them to redevelop these sites towards mixed-use areas combining housing and industry. This paper analyzes case studies on the Binckhorst and Plaspoelpolder sites in and around The Hague and the Buiksloterham site in Amsterdam in relation to the following themes: attractiveness of the site as a location for the introduction of housing, the environmental loading caused by combining industry and housing, and municipal strategies for redevelopment of the industrial estates. It was found that traditional amenities such as waterfronts can provide ample potential for housing development; that while there may be plenty of room for housing, much of it will be subject to unacceptable environmental hazards; that a cooperative enforcement style is used to mutual adapt the local interpretation of environmental standards to the interests of the mixed-use areas;; and that in all cases, local government became strongly involved in the property market in order to internalize the external effects of investments in the area.
\end{abstract}

Key words: Compact city, Industrial Estates, Mixed use, Housing.

\section{Short title: Strategies for introducing housing on industrial estates}

\section{Introduction}

Modern urban planning has been characterized by widespread rejection of the nineteenth-century style of urban development because of the high occupation density, nuisance due to industry and traffic, and poor housing conditions that it involved (Mumford, 1992). One widely adopted solution was to give planning authorities the power to enforce the separation of functions in urban development plans. For example, German local authorities were empowered to prevent the establishment of industry in certain areas (Sutcliffe, 1981, p. 33). Similar measures were introduced in the USA a little after 1910 (Fischel, 2004, p. 318). The idea was that working places, although located not too far from housing to reduce commuting time, should be separated from residential zones by green areas and sports fields. This principle was reiterated at the influential conference on 'The Functional City' of the CIAM (Congrès Internationaux d'Architecture Moderne) in 1933 (Mumford, 2000). 
The separation of functions has however been criticized, not only by authors from outside the planning movement such as Jacobs (1961), but also from within (Mumford, 1992; 2000). As a result, the promotion of mixed-use development has come to play an important part in the modern urban agenda. This approach has different local variants, known e.g. as the urban renaissance, compact-city policies and new urbanism (Stead \& Hoppenbrouwer, 2004; Hoppenbrouwer \& Louw, 2005).

Although there are now many examples of projects with mixed or even multiple (Louw \& Buinsma, 2006) land use, in which functions such as housing, commercial activities, leisure and infrastructure are combined in the same urban area, planners have gained less experience in the mixing of industry and housing in the same development. Areas comprising a mixture of housing and industry grew up in some older industrial cities such as New York (Angotti \& Hanhardt, 2001; Curran, 2007) and the Black Country of the West Midlands in the UK (Vigor, 1975). In general, these mixed developments date from before the introduction of zoning, which came too late to prevent this mixture of industry and low-income housing. Many of these areas house industries that pose serious health hazards in their own right and also attract high densities of noisy, heavy vehicles that emit unpleasant and toxic fumes and fine particulates and give rise to vibrations that can threaten the integrity of nearby buildings (Angotti \& Hanhardt, 2001).

The reaction against the atrocious living conditions in these old industrial cities led to the separation of industry and housing as a guiding principle in more recent urban development. The separation between housing and industries that create heavy pollution or other hazardous conditions and attract high densities of heavy vehicular traffic is still maintained in modern design practice, even though this generally involves widespread mixed-use development (Barnett, 2003, p.287).

Mixed-use development of industry and housing is feasible nowadays, because industry has changed. "Many large polluting industries have moved to other parts of the world or divided into smaller subcontractors. New technology has reduced risk from pollution. (..) New technologies have given birth to entirely new economic activities." (Angotti \& Hanhardt, 2001, p. 145). Production units are smaller and more flexible. Hence, much industry is compatible with residential use today. There are however still few examples of new communities where housing and industrial production are combined (Angotti \& Hanhardt, 2001). Industry is often left out of the picture because planners consider it to be less desirable and perhaps even incompatible with other land uses (Grant, 2002). Living close to industry may cause "severe discomfort", due e.g. to vibration in houses caused by a high-powered drop hammer forge (Vigor, 1975, 45) or heavy traffic on local roads. Moreover, proximity to industry can have a negative impact on the market value of housing (Rouwendal \& Van der Straaten, 2007). In view of the uncertainties involved, such mixed-use developments may be less attractive to property investors as well as to individual residents (Grant, 2002).

A number of Dutch local authorities are currently planning to introduce housing on existing industrial estates as part of what is known in the Netherlands as a 'compactcity' policy, aimed at enhancing the urban environment. 


\section{Compact city policies in the Netherlands}

Compact-city policies were introduced in the Netherlands in the late 1970s and enjoyed their heyday in the 1980s (Faludi and Van der Valk, 1994). They led to a long-term resurgence of Dutch cities like Amsterdam, Rotterdam and The Hague (Turok and Mykhnenko, 2007): a period of decline during the 1970s was followed by substantial growth in the 1980s, 1990s and early 2000s. The concentration of development in inner-city areas is still one of the cornerstones of Dutch spatial planning. Provinces like North and South Holland, Utrecht and North Brabant use strict urban growth boundaries around urban areas to contain urban growth. Constructing new homes on previously developed land in built-up areas of cities and towns is part of this policy.

A compact city was originally defined as a continuous urban area of a size that allowed optimal use of the existing services, employment and infrastructure (Zonneveld, 1991, 50). It was argued in support of the compact-city policy that suburbanisation was selective, promoted spatial segregation and last but not least hindered social revaluation of cities (Faludi and Van der Valk, 1994). Dutch compactcity policy was originally a local initiative facilitated by central government both by the provision of urban development grants and by pursuing a spatial policy that restricted urban development on greenfield sites.

Compact-city policies do not however offer a panacea for all urban problems (Healy and Birell, 2004). While they counter the destruction of the rural environment due to urban sprawl, other environmental benefits claimed for such policies are not undisputed. The idea that concentration reduces travel distances and promotes a shift of transportation preferences to non-motorized vehicles and public transport is open to debate (Maat et al., 2005). Most notably, a compact-city policy places the environment under certain strains such as the commotion of city life, noise, poor air quality, dust, toxic pollutants and a higher risk of disasters. This complex of effects is referred to as the "paradox of the compact city". These urban environmental conflicts facing compact city areas require complex policy-making approaches (De Roo, 2000). The dilemmas involved have not however hampered the Dutch government from pursuing a resolute compact-city policy.

These conflicts between environmentalist and development-oriented views of the population density a city can house have also been noted in Great Britain (Gunn, 2006). The urban renaissance there led to a rethinking of views on urban capacity, with development-oriented studies identifying more potential for new housing on previously developed land (see also Oxley et al, 2005). It was also claimed that former environmentalist approaches "...failed to recognise the ability of people to alter their environment and to overcome the constraints" (Gunn, 2006, 415). However, Gunn criticizes the lack of awareness of the need for adequate infrastructure to cater for the new higher housing densities on previously developed sites, and refers to allegations of 'town cramming' (see also Dair \& Williams, 2005; Pacione, 2004). On the basis of research in Sidney, Bunker et al. (2005) conclude that piling '...higher density housing into already socially stressed areas may not produce sustainable social outcomes over the longer term' (see page 792 of their article). They therefore stress that planning must take into account the context in which development occurs. 
Dutch compact-city policies are, however, not primarily realized by building on green spaces inside the cities. This approach is opposed not only by local residents but also at local government level - a highly relevant fact, since local government plays a dominant role in the creation of housing in compact cities. Most of the new additions to the housing stock are being constructed in 'change-of-function' areas, e.g., former industrial estates, railway yards and sites previously occupied by army barracks, hospitals, schools and the like (Korthals Altes, 2007). The reasons for this are twofold. Firstly the renewal of old housing areas by demolition and rebuilding does not generally produce more homes, as the new homes tend to be much larger than the ones demolished. Secondly, vacant land is almost non-existent in Dutch cities (Wood, 1998).

The problem with the change-of-function approach is that it is relatively expensive, as it involves more than just the costs associated with simple brown-field sites, e.g. those for soil decontamination. The authorities do not usually wait until the land to be redeveloped is vacant, but start planning the work while the sites involved are still being used for their old purpose. This usually involves very high acquisition costs, since the existing land use is associated with a relatively high value - often higher than the residual value of the land for new development (Korthals Altes, 2007; cf. Oxley et al., 2005). This policy, aimed at preventing excessive use of new open space, is an essential part of current compact-city policies. It is however very costly, as we have seen, and national government grants are needed to finance it.

Some industrial estates do not lend themselves to complete transformation into housing development. Most of these industrial estates were created after World War 2 (see Louw (2000) for a description of this process), and the property values may still be relatively high. Moreover, while some industrial establishments may have relocated it may be too expensive to relocate all of them. There may also be other arguments for keeping some industry in the city, e.g. the jobs offered are important for the city (cf. Curran, 2007). The funds available for urban restructuring are currently diminishing, and the priority has shifted to the revitalization of post-World War 2 neighbourhoods. More recently, interest has arisen in the gradual introduction of housing on functioning industrial estates where some plants may represent a significant load on the environment. This is part of a process of gradual shift in the function of these areas away from industry and towards service-based activities that can more effectively be combined with housing.

\section{Three aspects of the introduction of housing in industrial estates}

We expect three factors to play a particularly important role in the creation of mixeduse areas of housing and industry, viz.: the attractiveness of the site as a location for housing development, the environmental loading of the location and local development strategies.

First of all, the site needs to be one where people would like to live. An industrial estate is not the most obvious choice of a setting for attractive new housing. Experience has shown, however, that a complete face-lift can create an attractive dwelling environment (Korthals Altes, 2007). In some cases, mixed-use areas combining housing and carefully selected other functions have proved very successful (Hoppenbrouwer and Louw, 2005). Former docklands that have been transformed into high-quality, high-price waterfront living environments are a good example of this 
(Gordon, 1997; Wigmans, 2001; Bunce and Desfor, 2007). This process can be bolstered by appropriate placemaking discourse (Raco, 2003). Experience has shown, however, that there are often limits to the market for blocks of flats in such developments.

The case studies discussed below do not start from a tabula rasa. It generally proves to be much more difficult to create an attractive dwelling environment on a mixed-use site where e.g. a concrete plant is still functioning near new housing. Failure to deal adequately with this issue may not only fuel criticism of "town cramming" but also deal a fatal blow to the viability of the project: if people don't like the housing enough to pay a decent market price for it, there will not be a sound financial basis for the redevelopment. Local government has an important role to play here.

The possibilities of mixing industry and housing in a given area may be limited not only by planning instruments created to promote functional separation of uses but also by environmental regulations promulgated to limit nuisance and protect residents from environmental hazards. Heavy-handed application of the relevant rules can sound the death knell to such developments.

A promising new approach developed in the Netherlands, known as the 'city-andenvironment' approach, may offer a way out of this impasse (De Roo, 2000; Glasbergen 2005). This replaces the regular top-down setting of norms by consultation between all interested parties aimed at innovative solving of the environment problems posed by urban development so as to reach a construction acceptable to all stakeholders, with the emphasis on the broader concept of improving the quality of life. The strict application of environmental standards may even be relaxed if it can be shown that this still represents no real risk to the persons concerned. The city-and-environment approach falls within the scope of what is known as 'decentralized reflexive environmental regulation' (Glasbergen, 2005).

In his doctoral thesis entitled Regulating Land and Pollution in China, Van Rooij (2006) describes the traditional style of enforcement as one of deterrence: enforcement agents '...go strictly by the book, without looking at the special circumstances of the violating actor in question' (see page 228). Enforcement is based on maximizing detection rate and sanction levels. The city-and-environment approach, however, is based on a cooperative enforcement style in which the idea is that '...in order to get sustained compliance, the agent and the regulated actor should understand each other and work towards compliance together' (see page 229). In this model the spirit rather than the letter of the law is central. Persuasion and education are considered to be more important than punishment. The idea is that "...cooperation enforcement only succeeds if enforcement agents and agencies have considerable discretion. Such discretion is necessary to find workable solutions for sustainable compliance, in which the circumstances of the regulated actor play an important role. Without sufficient discretion, agents will not be able to cooperate with the violator in finding such solution.' (Van Rooij, 2006, 229).

Dutch environmental agencies have been making increasing use of a cooperative enforcement approach (Glasbergen, 2005). 
The City-and-Environment approach has been launched as an experiment for 25 projects between 1-1-1999 and 31-12-2003. On the basis of evaluation of the results of these pilots, the Dutch Parliament passed the Interimwet Stad-en Milieubenadering (Interim Act for the City-and-Environment Approach) in 2006. This interim act allows local authorities to deviate from national environmental regulations as the third step in a procedure laid down in detail by the Dutch Ministry of Housing, Spatial Planning and the Environment - abbreviated VROM in Dutch (Ministry of VROM, 2005). The first step comprises integration of environmental aspects in spatial plans, and the taking of measures to combat pollution at source, at an early stage. One of the ways local authorities may combat pollution is by granting environmental permits. These permits must be renewed roughly every 10 years, and the new permit must take into account the current situation and measures introduced to make emissions as low as is reasonably possible (Berenschot, 2007). This permit procedure allows authorities to encourage users to lower emissions not only by introducing new technologies but also by changing company culture to make employees more environmentally minded. Local authorities may also impose additional requirements on existing permits. While local authorities are in principle obliged to compensate companies if they introduce new requirements during the life of the permit, this obligation may be lifted under certain conditions if the additional requirements have no impact on the operational management of the enterprises in question.

The second step involves exploration of tailor-made solutions to pollution problems if those adopted in step 1 do not work (Glasbergen, 2005). Only if those first two steps do not yield the desired effect may the parties involved consider deviation from the applicable environmental standards and regulations. It should be noted, however, that any environmental loading produced by departure from the relevant norms must be compensated for - not financially, but in terms of environmental measures - and preferably in the same environmental compartment. For example, the effect of high noise levels from an industrial plant on a block of flats can be compensated for by extra acoustic insulation between neighbouring flats.

Analysis of the learning outcomes of the above-mentioned pilot projects by the physical-planning and real-estate consultancy Ecorys-Kolpron (2002) showed that many respondents were of the opinion that the availability of an 'emergency exit' as an optional third step in the statutory procedure encouraged many municipalities to go ahead with projects characterized by high environmental thresholds, even though use was only actually made of this possibility in two out of the 25 cases. We expect this cooperative style of enforcement of environmental standards to play a significant role in promoting the introduction of housing on industrial estates in the future.

Local development strategies are a third aspect of the introduction process that may play a role. Planning instruments based on the idea of the functional city might not work as well in mixed-use developments (Angotti \& Hanhardt, 2001). Debates on land classes in zoning ordinances in relation to planning show that new ways of organizing planning may be needed to facilitate mixed-use development (Hirt, 2007). Traditional planning instruments, based on the separation of conflicting functions, do not deliver mixed-use areas. Mixed-use development demands a new approach, in which the quality of public space is important (Angotti \& Hanhardt, 2001): potential conflicts in this field are not only about effects on buildings but also about those on 
public spaces - for example, balancing the relative value of new transport routes and playgrounds.

Local government has traditionally played a strong role in land development in the Netherlands (Needham, 1997). Municipalities generally follow a direct development strategy, i.e. they buy the land, lay down the necessary infrastructure and sell plots to development companies or other parties that are responsible for the actual building.

In the present paper, the above-mentioned three aspects are used as a basis for analysis of the introduction of housing on three industrial estates in the Netherlands: Plaspoelpolder in Rijswijk (a suburb of The Hague), Binckhorst in The Hague and Buiksloterham in Amsterdam. As the transformation of these areas is not finished yet, this article cannot provide an end evaluation of the cases, nevertheless, it analyses how these three aspects play a role in structuring the approach used in the cases.

\section{Plaspoelpolder}

Plaspoelpolder covers an area of 100 ha and was developed by a joint corporate body set up by the municipalities of Rijswijk and The Hague, starting in 1953. The area is currently estimated to house 428 companies and 21,108 employees. The authorities concerned now consider that the area is in need of 'sustainable revitalization'. Wellbalanced addition of housing should help to give Plaspoelpolder a new image. Industries that place a high load on the environment will be excluded; the ultimate aim is to transform the industrial estate into a 'flexible work city' offering a rich mix of functions and 'an intensified activity level' (Municipality of Rijswijk, 2006, pp. 2627). The introduction of housing, amenities with a wider user group (such as restaurants and cafeteria) as well as new small and medium-sized businesses and offices for companies in the services sector will contribute to the desired new image. Housing in Plaspoelpolder may be introduced at three scale levels: that of a single (e.g. business-related) building, the block level and the area level. Creating marshy banks along the watercourses in the area will improve the ecological quality.

The housing is to be introduced in a small harbour area called Landtong (the 'Tongue of Land'); see Figure 1. The site, near an existing residential area, is regarded as a prime candidate for redevelopment thanks to its two harbour basins and extensive waterfront.

\{Figure 1 Harbour area 'Landtong' as possible location for housing (Municipality of Rijswijk, 2006, p.59)\}

The area is currently in decline, with a low occupancy level and little investment potential (Municipality of Rijswijk, 2006). Lot sizes, building heights and business types vary. A concrete plant (generating a heavy environmental load) is the last vestige of industry left in the area, and must remain since it will be difficult or impossible to find an alternative location for it. In the current situation, the Landtong is difficultly accessible and the southern basin is hidden behind private lots and quays.

The plan is to make the quays more accessible and open them to the public. A passage cut through the buildings in the direction of the basins could improve the accessibility and visibility of the new developments (Municipality of Rijswijk, 2006). A 'flexible- 
use' building with public waterfronts could initially be occupied by small businesses and later transformed into housing over time.

The above-mentioned concrete plant is the main environmental challenge to the introduction of housing on the Landtong. As the local authority decided to keep the plant at its present location, all other developments have to be tailored to its presence (Figure 2). If housing is to be introduced in the vicinity of the concrete plant, pollution from the plant will have to be controlled at source, the houses will have to be provided with acoustic insulation and the urban development plan will have to include extra acoustic buffers to reduce noise pollution at various sensitive locations. The municipal planning department and the environmental management department of the province of South-Holland, (which is responsible for granting the plant's environmental management permit) will work together to draw up a number of urban development scenarios. The route designed for the transport of hazardous substances has been modified to allow the first batch of houses to be built.

\{Figure 2 Environmental preconditions for redevelopment of the Landtong site in Plaspoelpolder (Municipality of Rijswijk, 2006, p.20)\}

The joint corporate body set up by the municipalities of The Hague and Rijswijk in the 1950s bought the land, provided infrastructure and disposed of it to businesses. It is still the largest landowner in the area. It is currently actively acquiring land for the redevelopment and negotiating the relocation of the present occupants and the termination of existing rental agreements (Industrieschap Plaspoelpolder, 2003). While such management agencies traditionally focus on the settlement of (small) businesses, the current expectation is that investment in housing development in Plaspoelpolder will encourage further investment in neighbouring areas. The concrete plant is the last industrial enterprise with a structural need for water transport, and the market demand for such activities is diminishing. Nevertheless, the structural vision for redevelopment of Plaspoelpolder sees preservation of the plant at its present location as an essential precondition for success of the whole scheme. The redevelopment of the Landtong and its harbour basins for residential and recreational purposes may stimulate the development of the adjacent commercial areas, raising land values and stimulating occupancy of the rest of Plaspoelpolder. The increased value of the land may also make it possible recoup the costs of soil improvement needed to deal with the pollution left by previous industrial occupants. In view of the fragmented ownership of the land, the area has to be upgraded lot by lot. It goes without saying that the land-use plan for Plaspoelpolder has to be modified to permit the proposed functional shift towards housing.

To sum up, the local authorities expect the introduction of housing and attractive modern amenities to allow new lifestyles to flourish alongside new cleaner businesses. The introduction of housing is seen primarily as a means of stimulating the development of industry in this area. In view of the decision to keep the concrete plant at its present location, effective environmental measures will have to be taken to safeguard the occupants of the neighbouring residential accommodation. The renewal of the plant's environmental permit will be made contingent on investment by the owners to combat noise pollution and other environmental emissions at source if needed in the interests of nearby housing. A cooperative enforcement style (described 
above) is used, i.e. decisions are based on negotiation with all stakeholders. At the same time, the amended noise pollution act allows municipalities to accept higher noise emission levels from the plant and to take their own measures to reduce the noise nuisance to nearby residents to acceptable levels. If current noise-abatement and environmental legislation do not offer enough room from manoeuvre here, the abovementioned city-and-environment approach allows the local authorities an appreciable degree of flexibility in setting environmental requirements for soil pollution, noise, odour and ammonia emissions.

\section{Binckhorst}

Binckhorst covers an overall area of 124 ha in the city of The Hague. The local authorities have chosen this site as one of 10 priority areas in the region (City Region of Haaglanden, 2007), and have launched a new vision for transformation of this industrial estate into a high-density, mixed-use urban development (Municipality of The Hague et al., 2006; 2007). They criticize the present spatial and economic qualities of the area, in particular what they see as undesired settlement of marginal functions in the area, low occupancy, excessive land use by existing businesses and industries, soil pollution and a low level of investment in the area as a whole (Municipality of The Hague, 2005). The visual impression left by the area as a whole is highly variable, ranging from the temporary seat of the International Criminal Court surrounded by high-quality offices to a breaker's yard and other heavy industry.

\{Figure 3 The Binckhorst harbour area, showing the asphalt and concrete plant (1) and concrete plant (2) among other existing industrial functions together with proposed housing and industrial development (shaded) (after: Municipality of The Hague, 2005)\}

The idea is to intensify land use from a floor space index of 0.6 to 1.0 by adding 5000 dwellings and $85,000 \mathrm{~m} 2$ of office space. More than $50 \%$ of the net area of the Binckhorst site will be transformed. Heavily polluting industries like waste-treatment plants, car-recycling yards and concrete plants currently occupy $10 \%$ of the area. Some of these occupy strategic positions where housing development is projected. Twenty-five of these plants will be moved to other locations (Municipality of The Hague, 2005; 2007b). The redevelopment plan states that new businesses will be 'clean, labour-intensive and city-oriented' like creative design studios.

The location close to the city centre will be exploited by the introduction of housing, upgrading the waterfront of the old harbour area, laying out a new city park and attracting service industry. Existing companies will have to cluster together, making more effective use of the land they occupy. Facilities for festivals and other events, together with a pioneer catering industry, would help to create a new ambience that would attract businesses and residential occupants. Links to the road network and public transport will be improved. A proposed road tunnel connecting Binckhorst with the motorway leading to the centre of The Hague is seen as one of the main preconditions for success of this plan (Smit, 2007).

Existing functions and environmental quality have been surveyed to provide a basis for balancing territorial ambitions with environmental constraints (De Sain \& Van Zwieten, 2007). 'Environmental plans' are then drawn up to reflect the opportunities and challenges for achieving the targets set for various environmental compartments 
like soil, noise and air pollution. Plans are made to relocate industries that do not fit into the proposed transformation framework, such as two concrete plants and an asphalt centre located in harbour areas where housing is planned (Municipality of The Hague, 2005). The perspectives the city is able to offer these businesses will determine the pace of transformation. The municipality believes that it has found suitable alternative locations for the firms concerned (cf City Region of Haaglanden, 2007).

It may also be possible to find new sites for polluting industries in the region outside the city boundaries. The municipality of The Hague and the administrative council of Haaglanden (the metropolitan region of Greater The Hague) are therefore currently working on a regional strategy for industrial estates that will function as a guideline for agreements on quality, size and phasing of such sites. Alternative locations will be reserved for businesses removed from Binckhorst. For example, the industrial board for Harnasch Polder, between The Hague and Delft, has earmarked 12 ha for such purposes, while the Provincial authorities of South Holland have designated an area in Pijnacker-Nootdorp, to the southeast of The Hague, for the location of cardismantling, demolition and metal-processing firms (Municipality of The Hague, 2007a).

The Hague has a tradition of direct development - which means, as mentioned above, that the municipality plays the main role in planning development and actually owns much of the land concerned. At Binckhorst, however, most of the land is privately owned and the municipality aims to collaborate with private agencies to spread the land-development risks. It is negotiating to purchase the land owned by companies moving away from Binckhorst, such as the above-mentioned concrete and asphalt plants. Compulsory purchase is considered to be too expensive at the moment, as this would involve compensating the companies concerned not only for the economic value of the site but also for the costs of relocation at a moment not chosen by the companies. Compulsory purchase is kept as a last resort in case the parties fail to reach agreement. The municipality has also established pre-emption rights over part of Binckhorst. This means that sellers of land must first offer the land to the municipality, which has a right to negotiate the price and other conditions of sale. Only if the latter does not wish to buy, or is unwilling to pay the market price set by a judge on the basis of expert advice, can the land be sold to a third party.

The municipality has further stipulated that no more building permits will be issued on the basis of the old development plan during the preparation of the new one (Municipality of The Hague, 2006). However, a building permit may be granted if the proposed new building fits in the new development vision. Local authorities have wide discretionary powers at this stage of the development process (see also Thomas et al, 1983).

The municipality is working in close cooperation with markets agents on the redevelopment of Binckhorst, and has signed a letter of intent with two private partners (Municipality of The Hague et al., 2006). This approach is expected to help in fostering a businesslike attitude to the development process and to protect against the risk of changes in government policies. 
To sum up, the transformation of the Binckhorst site is aimed at creating a new innercity living environment that will cater for new lifestyles and at attracting cleaner businesses like creative design studios and city-oriented small and medium-sized companies. Amenities serving a wide user group will also be created, alongside public spaces linking the residential and industrial functions. An area-based environmental policy has been adopted. The scope of the project extends beyond the municipal boundaries, in the sense that measures have been taken to facilitate relocation of businesses leaving Binckhorst at a number of sites in the Greater The Hague region. The municipality owns a limited amount of land in Binckhorst, but is prepared to use direct development where possible. Where it is not, public-private initiatives are sought at two levels: that of the area as a whole and that of the individual site.

\section{Buiksloterham}

Buiksloterham is an industrial estate of about 100 ha in area, divided from the centre of Amsterdam by the IJ, a former arm of the sea. The industrial activities that were traditionally located here have given way to small-scale businesses such as media and creative companies. This change, which can also be found on adjacent sites, has created a 'new working climate' (Municipality of Amsterdam, 2006, p.13).

Nevertheless, some polluting industries are still located in Buiksloterham. This site is being redeveloped within the framework of the large-scale transformation of the whole northern shore of the IJ towards a mixed-use urban area (Figure 4). There will be major investment in public space, new bridges will be constructed, and bus and ship links will be improved. The location - close to the city centre, though on the 'wrong side' of the IJ - and the possibility of living close to the water give the site considerable market potential.

\{Figure 4 Buiksloterham (Municipality of Amsterdam, 2007, 10)\}

This development forms part of the Amsterdam Structure Plan 2003-2010 'Opt for urbanity' (Kiezen voor stedelijkheid), which promotes the realization of intensive and mixed-use environments.

The city is trying to meet market demand by introducing creative industries and attracting pioneer businesses that like to establish themselves in areas in transition (Municipality of Amsterdam, 2007). The plan is to realize 2,000 new dwellings for a variety of lifestyles (30\% social housing) together with the necessary amenities such as shops and schools in the period up to 2015. Waterfronts will be made public and bordered with green shores and pedestrian and cyclist routes. Housing will contribute to the area's safety and vitality by establishing a varied social presence at all times. Residential and work functions will be mixed at area level, block level and individual building level (Teppema, 2004). Housing will be the dominant function along the shore of the IJ and by the harbourside in the centre of the area. It is presently too early to tell whether the local authority succeeds in creating attractiveness.

Environmental considerations play an important role in the spatial planning of this area. The development plan (bestemmingsplan) for Buiksloterham allows for a certain amount of noisy industry. A noise contour separates noise sources from noisesensitive functions like housing. To permit the introduction of housing within the noise zone, the noise level inside that zone must be lowered. This can only be achieved through good communication with the industries involved. The municipality 
of Amsterdam holds regular consultations with the companies in question to discuss individual requirements and future possibilities like expansion and relocation. Traffic noise means that the preferred noise level of $50 \mathrm{~dB}(\mathrm{~A})$ cannot be met everywhere in Buiksloterham. In the long run, the housing programme will even result in an overall increase in traffic noise. Housing can only be built here by allowing higher noise levels at less critical sites, taking physical measures to reduce noise where necessary, introducing alternative routes for goods transport and a $30 \mathrm{~km} / \mathrm{h}$ maximum speed limit, and by other urban planning measures.

In the environmental impact assessment for the area two alternative scenarios for development are compared, that is, spontaneously development by individual landowners versus active transformation of the area by government intervention (Municipality of Amsterdam, 2005). This assessment indicates that many structural environmental problems will not be adressed in the model of spontaneous development and that active redevelopment may be instrumental in changing the environmental conditions for the area. However, active transformation may miss the chance that choices of individual landowners may contribute to the process positively. A combination of both strategies is seen as the preferred solution in which active intervention will be used to remove some bottlenecks, which will facilitate a wider field of choice for spontaneous development.

Noise abatement permits that allow companies to make more noise on paper than they actually emit will be revised to include more realistic limits, since excessive nominal limits place undue restrictions on the housing construction that is permitted. The authorities have imposed additional requirements on establishments concerning the measured noise levels 50 metres from the premises during the day, the evenings, and the nights (see e.g. Gemeente Amsterdam, 2007). The mixed-use development and the structure plan for the city as a whole are cited in the initial considerations as justification for these orders. The order for a given establishment is based on a survey of the establishment's existing activities, a visit and consultation with the company's management, and concludes by stating that the establishment can comply with the new requirements without changing its operational management. The parties concerned can lodge an appeal against the order at the competent administrative court. In general, extensive informal proceedings precede the issue of such an order. The Chamber of Commerce (abbreviated KvK in Dutch) advises companies not to wait for a formal draft order, but to discuss the issues involved with civil servants on the basis of an initial unofficial draft, as it is much easier to change requirements at this stage without entering time-consuming formal proceedings (KVK, 2007).

Amsterdam has a strong tradition of direct development. Since 1896, the policy has been for the municipality to retain bare ownership and sell a right of 'emphyteusis' (erfpacht in Dutch), a term usually imprecisely translated as 'leasehold'. In Amsterdam, however, it is an enduring title, comparable in some aspects to freehold with a restrictive covenant, that may be assigned to private agents. The holder of this title is usually not allowed to change the function of the land, and the municipality may demand compensation for changing rights (De Wolff et al., 2006, p. 59). The municipality owns $75 \%$ of the Buiksloterham area. However mostly this is only bare ownership. Following the above tradition, the municipality is acquiring land and rights of emphyteusis (Figure 5). If landowners create added value by changing the 
function into housing themselves the ground rent will usually rise, as the conditions attached to the right of emphyteusis must change. The land is disposed of in 'building packages' with a specific redevelopment programme for larger lots, to give market agents more scope for optimizing functions within each lot.

\{Figure 5 Municipal investment area in Buiksloterham (Municipality of Amsterdam, 2007, p.64)\}

Just as in the case of the Binckhorst project in The Hague, the municipality has decided to prepare a new development plan for the area in question, with the same discretionary powers as those referred to above, to permit a flexible and gradual transition to the new situation.

To sum up, the Buiksloterham site offers great scope for creating an attractive residential environment in combination with small-scale businesses. However, dealing with the environmental load due to the variety of noise-producing activities remaining in the neighbourhood is a complex issue. The municipality has an active role to play here, and will have to persuade the companies concerned to take effective measures to reduce noise emission. The local tradition of direct development and the wide experience gained in redeveloping harbour areas in Amsterdam will facilitate the municipality's tasks. In the long run, ground-rents will rise as land use is transferred to housing.

\section{Discussion and Conclusion}

The cases analysed in this paper show that the introduction of housing alongside industrial and commercial functions forms part of a wider approach to the reorganization of industrial land in a post-industrial era. The ideas developed by Richard Florida in The Rise of the Creative Class (Florida, 2002) and by Jane Jacobs in The Death and Life of Great American Cities (Jacobs, 1961) are playing a role here, alongside more traditional concepts concerning efficient land use (see also Hoppenbrouwer and Louw, 2005; Porter and Barber, 2006). In this context, housing is seen as an instrument for changing the local urban environment to make it more attractive for other businesses. This represents a shift away from past Dutch urban planning practices, where housing was the key issue. This new approach may be seen as a correction to previous single-function development strategies in the direction of a more mixed-use urban fabric.

It will be clear from the above that the current approach to mixed-use development is radically different from that found in old industrial cities, which grew up before the introduction of zoning.

The three cases discussed all involve the introduction of housing at waterfront sites and transformation of quaysides into public space in the interests of creating an attractive living environment. This approach is not in itself new, and confirms the well-established idea that 'waterfronts matter' (Bunce and Desfo, 2007, p. 252). An interesting topic for future research would be to consider whether sites without existing water features would be equally effective for the creation of mixed-use developments. One drawback of the use of waterfront locations that should be mentioned is the likelihood that heavy industry still dependent on inland shipping may 
be located here. All three of the sites we studied still include noisy concrete plants for which no other suitable location can be found.

The attractiveness of the site also depends on the way environmental stress - in particular noise - is handled. All case studies show close interaction between the various stakeholders on the subject of future developments and the way environmental nuisance can be reduced, with a strong tendency towards a cooperative rather than deterrence-based style in the enforcement of environmental regulations (Van Rooij, 2006). The 'city-and-environment' approach based on recent Dutch legislation, which offers scope for a flexible approach to the implementation of environmental standards, helps to support these processes. Though this option of relaxing environmental requirements, which demands providing extensive evidence and paper work, such as, proof that other measures are insufficient to achieve economical and efficient land use, is rarely used in practice, the fact that this possibility exists often helps to facilitate negotiations.

The success of a flexible approach to the setting and enforcement of environmental permits, based on cooperation between the local authorities and the industries involved, offers promise for the introduction of mixed-use areas elsewhere. The three cases studied above also make it clear, however, that not all industrial functions can be mixed with housing.

A regional approach to the relocation of industry may be useful, as it is often difficult to find new sites for businesses generating a high level of environmental nuisance within the municipal boundaries. In many cases, inner-city sites are no longer the best place for industry anyway, and plans to transform an area from pure industrial use to mixed use may actually facilitate the move to a more suitable location for many companies. Such moves may contribute to the phenomenon that land use for industry is growing faster than for any other function in the Netherlands (Needham \& Louw, 2006). Industry has a larger environmental claim on land, and is more difficult to accommodate in a mixed-use compact city. Compact-city polices may stimulate industrial suburbanization by a 'housing first' policy in inner-city areas. Most relocating industries move to industrial areas where they can get more space (Ebels, 1997, pp. 322-323). At the same time, compact-city policies are stimulating a higher building density in new housing areas.

The idea that the transformation of an industrial estate to a mixed-use area requires a coordinated regional approach fits in well with ideas about the relationship between regional co-operation, urban fragmentation and urban sprawl (Yin \& Sun, 2007). While the relocation of industry may result in more extensive land use by individual companies, it also facilitates the creation of attractive mixed-use cities with a higher overall occupation density.

In all cases studied, local government played a dominant role in buying land, servicing it and co-ordinating the redevelopment process. This may allow the municipality to internalize the external effects that reducing nuisance has for the development value of land in the area. The development plan is used strategically. In all three cases, the municipality made a formal decision to draw up new development plans and to cease to issue building permits based upon the old plan - while still retaining the power, subject to Provincial approval, to grant permits for new building 
work that fits within the new development vision for the area. This approach stimulates the flow of capital aimed at improving the structural quality of the area.

The above-mentioned policy of internalizing external effects is not watertight, as no formal relationship between development rights and payments made to improve the area in question has yet been established in the Dutch legal system (apart from cases where the municipality owns the right of emphyteusis). This may provoke debates about new legal instruments. On the other hand, no legal instrument can pull money out of a hat in the absence of added value. The costs of brownfield redevelopment are often higher than the direct property income. The municipality, which may benefit from government development grants, can play a strategic role in boosting the introduction of housing in inner-city industrial estates.

The compact-city policy remains a key element of Dutch urban planning. The transformation of post-World War 2 single-use industrial estates into mixed-use urban development meets society's needs. The question remains whether such mixed-use areas simply represent a transitional phase towards complete gentrification and removal of all industry from the inner city or whether they are a more or less permanent addition to Dutch urban fabric.

In relation to the wider agenda of promoting mixed-use areas in cities as part of an urban agenda, the experience reported above shows that the introduction of housing on industrial estates can be feasible. This approach will however in general involve the combined use of new ways of promoting potentially attractive areas, reducing environmental nuisance and flexible use of planning instruments that goes far beyond traditional zoning procedures.

\section{References}

Angotti, T. \& Hanhardt, E. (2001) Problems and Prospects for Healthy Mixed-use Communities in New York City, Planning Practice and Research, 16, 145-154

Barnett, J. (2003) Redesigning Cities: Principles, Practice, Implementation, (Chigago: Planners Press)

Berenschot (2007) Kritische massa in beeld: Onderzoek vergunningverlening en handhaving Wet milieubeheer, Berenschot, Utrecht, available online at http://www.vrom.nl (accessed 11-12-2007).

Bunce, S. and Desfor, G. (2007) Introduction to "Political ecologies of urban waterfront transformations", Cities, 24 (4), 251-258.

Bunker, R., Holloway, D. and Randolph, B. (2005) 'Building the Connection Between Housing Needs and Metropolitan Planning in Sydney, Australia', Housing Studies, 20:5, $771-794$

City Region of Haaglanden (2007), Ontwerp Regionaal Structuurplan Haaglanden 2020 - Sterk in internationale netwerken van bestuur, technologie, agrologistiek en toerisme, The Hague

Curran, W. (2007). 'From the Frying Pan to the Oven': Gentrification and the Experience of Industrial Displacement in Williamsburg, Brooklyn. Urban Studies, 44(8), 1427 - 1440.

Dair, C. \& Williams, K. (2006). Sustainable land reuse: the influence of different stakeholders in achieving sustainable brownfield developments in England Environment and Planning A, 38, 1345-1366. 
De Roo, G. (2000). Environmental conflicts in compact cities: complexity, decisionmaking, and policy approaches Environment and Planning B: Planning and Design, 27, 151-162.

De Sain, M \& Van Zwieten, Y. (2007) Milieutoets bij het Masterplan Binckhorst (Environmental examination with the Masterplan Binckhorst), DHV, Amersfoort.

De Wolff, H.W. (2006), Toekomst van het Haagse gronduitgiftesysteem, Onderzoeksinstituut OTB, Technische Universiteit Delft, Delft.

Ebels, H.J. (1997) Oudere stadsdelen en de ruimtelijke effecten van bedrijfsverplaatsingen, $\mathrm{PhD}$ thesis with English summary, University of Amsterdam, Amsterdam.

Ecorys-Kolpron (2002). Inventariseren/uitdiepen praktijkervaringen Stad \& Milieu, Rotterdam, Ecorys. Available from http://www.vrom.nl.

Faludi, A. \& Van der Valk, A.J. (1994) Rule and Order: Dutch Planning Doctrine in the Twentieth Century, Kluwer Academic, Dordrecht.

Fischel, W.A. (2004) An economic history of zoning and a cure for its exclusionary effects, Urban Studies, 41, 317-340.

Florida, R. (2002) The Rise of the Creative Class, (New York: Basic Books).

Gemeente Amsterdam (2007) Nadere eis op grond van artikel 5, eerste lid, onder a, en voorschrift 4.1.3 juncto 4.1.1 van het Besluit opslagen transportbedrijven milieubeheer, Behandelnummer N06/9664 DMB 2007 Dossiernummer 85559, Amsterdam. Aavailable http://dmb.asp4all.nl. (accessed 12-12-2007)

Gordon, D.L.A. (1997) Financing urban waterfront redevelopment, Journal of the American Planning Association, 63, 244-265.

Glasbergen, P. (2005) Decentralized reflexive environmental regulation: Opportunities and risks based on an evaluation of Dutch experiments, Environmental Sciences, 2(4), 427-442.

Grant, J. (2002) Mixed Use in Theory and Practice: Canadian Experience with Implementing a Planning Principle, Journal of the American Planning Association, 68, 71-84.

Gunn, S. (2006) The changing meaning of urban capacity, Town Planning Review, 77(4), 403-421.

Healy, E. \& Birrell, B. (2004) Housing and community in the compact city (Ahuri, Melbourne)

Hirt, S. (2007) The Devil is in the Definitions, Journal of the American Planning Association, 73, 436-450.

Hoppenbrouwer, E. and Louw, E. (2005) Mixed-use development: Theory and practice in Amsterdam's Eastern Docklands, European Planning Studies 13(7) 967-983.

Industrieschap Plaspoelpolder (2003), 50 jaar Industrieschap Plaspoelpolder, Rijswijk, Industrieschap Plaspoelpolder

Jacobs, J. (1961) The Death and Life of Great American Cities (London: Pimlico).

Korthals Altes, W.K. (2007) The impact of abolishing social-housing grants on the compact-city policy of Dutch municipalities, Environment and Planning A, 39, $1497-1512$.

KVK (2007) Tips bij het aanvragen van een milieuvergunning, Kamer van Koophandel, Woerden. Available from http://www.kvk.nl (accessed 12-122007).

Louw, E. (2000) The production of business sites in The Netherlands, Tijdschrift voor Economische en Sociale Geografie, 91(1), 85-91. 
Louw, E. and Bruinsma, F. (2006) From mixed to multiple land use, Journal of Housing and the Built Environment, 21(1), 1-13.

Maat, K., van Wee, B., Stead, D. (2005). Land use and travel behaviour: expected effects from the perspective of utility theory and activity-based theories Environment and Planning B: Planning and Design, 32, 33-46

Ministry of VROM (2005) New law for better living quality in Dutch municipalities, Ministerie van VROM, Den Haag. Available from www.vrom.nl/pagina.html?id=2706\&sp=2\&dn=5101 (accessed 12-12-2007)

Mumford, E. (2000) The CIAM Discourse on Urbanism, 1928-1960 (Cambridge/London: MIT Press).

Municipality of Amsterdam (2005) MER Herinrichting Buiksloterham/Overhoeks te Amsterdam (EIA Redevelopment Buiksloterham/Overhoeks in Amsterdam), Gemeente Amsterdam, Amsterdam http://www.noordwaarts.nl (accessed 10-042008)

Municipality of Amsterdam, (2006), Erfpacht in Amsterdam-Vervroegde wijziging erfpacht. http://www.erfpacht.amsterdam.nl (visited 30-4-2007)

Municipality of Amsterdam (2007). Investeringsbesluit Buiksloterham - Transformatie naar stedelijk wonen en werken, Amsterdam. Available from http://www.noordwaarts.nl/

Municipality of Rijswijk (2006). Stedenbouwkundige Structuurvisie Plaspoelpolder, Rijswijk, Rijswijk

Municipality of The Hague, (2005), Gebiedsvisie Plus Binckhorst, The Hague.

Municipality of The Hague, (2006). Voorstel van het college inzake voorbereidingsbesluit Binckhorst, The Hague

Municipality of The Hague (2007a). Voorstel van het college inzake update bedrijventerreinenstrategie 2005-2020, Den Haag

Municipality of The Hague (2007b), Atlas Bedrijvenlocaties Den Haag 2007, The Hague

Municipality of The Hague, BPF Bouwinvest en Rabo Vastgoed (2006). Gebiedsconcept Nieuw Binckhorst, The Hague

Municipality of The Hague, BPF Bouwinvest and Rabo Vastgoed (2007). Nieuw Binckhorst: Beslisnotitie haalbaarheidsstudie, The Hague. Available from http://www.wereldstadaanzee.nl.

Needham, B. (1997). Land Policy in the Netherlands, Tijdschrift voor Economische en Sociale Geografie, 88, 291-296.

Needham, B. \& Louw, E (2006), Institutional Economics and Policies for Changing Land Markets: The Case of Industrial Estates in the Netherlands, Journal of Property Research, 23(1), 75-90

Oxley, M., Golland, A. \& Weston, R. (2005). Urban residential development, economic viability and urban capacity studies, Journal of Housing and the Built Environment, 20(2): 153-166.

Pacione, M. (2004). Household growth, housing demand and new settlements in Scotland, European Planning Studies, 12(4), 517-535.

Porter, L. and A. Barber (2006) The meaning of place and state-led gentrification in Birmingham's Eastside, City, 10(2), 215-234.

Raco, M. (2003) Assessing the discourses and practices of urban regeneration in a growing region, Geoforum, 34(1), 37-55. 
Smit, P.W.M. (2007) Nut en noodzaak Trekvliettracé en stand van zaken OV verbinding Binckhorst, Letter of the alderman responsible for traffic, Binckhorst, Inner city and environment, to the council committee on Traffic and Environment of 10 April 2007, Municipality of The Hague, http://zbs.denhaag.nl/risdoc/2007/RIS145178.PDF

Stead, D. and Hoppenbrouwer, E. (2004) Promoting an urban renaissance in England and the Netherlands, Cities, 21(1), 119-136.

Sutcliffe, A. (1981) Towards the Planned City: Germany, Britain, the United States and France, 1780-1914 (Oxford: Basil Blackwell).

Teppema, A. (2004), Wonen tussen de bedrijven door, Plan Amsterdam, 10(7), 1-20

Thomas, D., J. Minett, S. Hopkins, S. Hamnett, A. Faludi and D. Barrell (1983). Flexibility and Commitment in Planning. Martinus Nijhoff Publishers, The Hague/Boston/London.

Turok, I. and Mykhnenko, V. (2007) The trajectories of European cities, 1960-2005, Cities, 24(3), 165-182.

Van Rooij, B. (2006) Regulating Land and Pollution in China: Lawmaking, Compliance, and Enforcement; Theory and Cases (Leiden, Leiden University Press) https://openaccess.leidenuniv.nl/dspace/bitstream/1887/5433/1/Thesis.pdf (accessed 2 May 2007)

Vigor, M. (1975) Industry as neighbour in urban areas, Journal of Environmental Planning and Management, 17, 40-55.

Wigmans, G. (2001) Contingent governance and the enabling city: The case of Rotterdam, City, 5, pp. 203-223.

Wood, B. (1998). Vacant Land in Europe, Lincoln Institute of Land Policy Working Paper WP98BW1 (Lincoln Institute of Land Policy, 113 Brattle Street, Cambridge MA 02138).

Yin, M. \& Sun, J. (2007) The Impacts of State Growth Management Programs on Urban Sprawl in the 1990s, Journal of Urban Affairs, 29(2), 149-179.

Zonneveld W, 1991 Conceptvorming in de ruimtelijke planning: Encyclopedie van planconcepten, [Concept formation in spatial planning: Encyclopedia of planning concepts] (University of Amsterdam, Amsterdam)

Zonneveld, W. (2005). "In search of conceptual modernization: The new Dutch 'national spatial strategy'." Journal of Housing and the Built Environment 20(4): 425-443. 